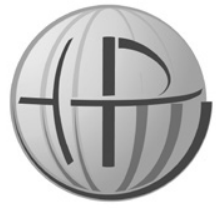

Horyzonty Polityki 2021, Vol. 12, No 40 OPEN ACCESS

\author{
Kamil Roman \\ http://orcid.org/0000-0002-1543-1343 \\ Uniwersytet Marii Curie-Skłodowskiej w Lublinie \\ kamilroman61@gmail.com
}

\section{Arkadiusz Tomaszek}

http://orcid.org/0000-0002-3145-2056 Uniwersytet Ekonomiczny w Krakowie arkadiusz.tomaszek@knro.uek.krakow.pl

DOI: $10.35765 /$ HP.2043

\title{
Postrzegany wpływ COVID-19 i związanych z nim ograniczeń dla młodych ludzi w Polsce
}

\section{Streszczenie}

CEL NAUKOWY: Celem naukowym niniejszego artykułu jest zbadanie postrzeganego wpływu COVID-19 i związanych z nim ograniczeń wśród młodych ludzi w Polsce. Analiza koncentruje się na zbadaniu opinii i oczekiwań ludzi młodych dotyczących wprowadzonych obostrzeń oraz ich wpływu na swobody obywatelskie poprzez zbadanie tempa, celowości oraz metod ich komunikowania przez ustawodawcę.

PROBLEM I METODY BADAWCZE: Głównym problemem badawczym jest określenie, w jaki sposób wprowadzane obostrzenia związane z COVID-19 oddziałują na młodych ludzi w Polsce. W tym celu - wykorzystując metodę sondażu diagnostycznego i autorski kwestionariusz ankiety - przeprowadzono badania w grupie 308 respondentów.

PROCES WYWODU: Wywód składa się z trzech części. W pierwszej z nich przeprowadzono analizę aktów prawnych, które zostały wydane w Polsce celem przeciwdziałania rozprzestrzeniania się COVID-19. Następnie opisana została metodyka badań, cel główny i cele szczegółowe, przedstawiono także charakterystykę badanych respondentów. W ostatniej części zaprezentowane zostały wyniki badań ankietowych.

WYNIKI ANALIZY NAUKOWEJ: Wyniki analizy dowiodły, że młodzi ludzie generalnie negatywnie oceniają zasadność i tempo wprowadzania obostrzeń dotyczących przeciwdziałania COVID-19. Ocena wprowadzanych ograniczeń pod kątem wpływu na swobody obywatelskie różniła się w przypadku płci 
respondenta. Mężczyźni za najbardziej utrudniający zakaz wskazywali ograniczenie działalności lokali gastronomicznych, z kolei kobiety uważały zakaz zgromadzeń za obostrzenie najbardziej ograniczające ich swobody obywatelskie.

WNIOSKI, INNOWACJE, REKOMENDACJE: Pandemia COVID-19 wpłynęła na wiele obszarów ludzkiego życia. W Polsce w związku z ogłoszonym 12 marca 2020 roku stanem zagrożenia epidemicznego (a od 20 marca stanem epidemii) wprowadzono szereg obostrzeń i zakazów, które zawiesiły lub czasowo ograniczyły funkcjonowanie wielu przedsiębiorstw, miejsc kultury i rozrywki. Wnioski, jakie płyną z niniejszej pracy są następujące. Ankietowani uznali, iż wprowadzane przez rząd obostrzenia nie były wprowadzane z odpowiednim wyprzedzeniem czasowym, a sposób wyjaśniania ich zasadności był niewystarczający. Przeprowadzone badania wpisują się w aktualny i ważny społecznie temat obostrzeń związanych z pandemią oraz stanowić mogą implikację do dalszych badań w tym zakresie, np. poprzez dokonanie analizy postrzegania obostrzeń w związku z rozprzestrzenianiem się COVID-19 przez inne grupy wiekowe. $Z$ pracy tej płyną pewne rekomendacje, które podkreślają konieczność wprowadzania zmian w porządku prawnym, z możliwie jak najdłuższym wyprzedzeniem czasowym.

\section{SŁowa KLUCzowe:}

obostrzenia prawne, koronawirus, COVID-19, Polska, młodzi ludzie

\section{Abstract \\ PERCEIVED IMPACT OF COVID-19 AND RELATED RESTRICTIONS ON YOUNG PEOPLE IN POLAND}

RESEARCH OBJECTIVE: The objective of this article is to examine the perceived impact of COVID-19 and related restrictions on young people in Poland. The analysis focuses on examining opinions and expectations of adolescents regarding the introduced restrictions and their impact on civil liberties by investigating the pace, meaning and ways in which they are declared by the lawmaker.

THE RESEARCH PROBLEM AND METHODS: The main research question is to determine how COVID-19 restrictions affect young people in Poland. Therefore, the research was conducted on a group of 308 respondents, using a diagnostic survey and questionnaire created for this purpose.

THE PROCESS OF ARGUMENTATION: The paper consists of three parts. The first part analyses the legal acts that have been issued in Poland in order to counter the spread of COVID-19. The second part describes the research methodology, objectives and hypotheses as well as the profile of the examined respondents. The last part presents the results of the research. 
RESEARCH RESULTS: The research results show that young people generally negatively assess the legitimacy and pace of the introduced COVID-19 restrictions. The assessment of those restrictions regarding their impact on civil liberties differed between males and females. Men indicated the closure of restaurants, bars and café as the biggest restriction, while women considered the ban on public assemblies as the restriction that most limited their civil liberties.

CONCLUSIONS, INNOVATIONS, AND RECOMMENDATIONS: The COVID-19 pandemic has affected many areas of everyday life. In Poland, due to the state of epidemic emergency announced on March 12, 2020 (and the epidemic state on March 20, 2020), a number of restrictions and bans were introduced, which suspended or temporarily limited the functioning of many businesses, cultural and entertainment centres. The study concludes that according to the respondents, the restrictions introduced by the government were implemented hastily, and their justification was insufficient. The conducted studies present an important and present issue of the COVID-19 restrictions and may provide a basis for further research in this area, e.g., an analysis of the perception of pandemic restrictions among different age groups. The research also emphasizes that any changes to the legal order must be introduced in advance.

\section{KeYwORDS:}

legal restrictions, coronavirus, COVID-19, Poland, young people

\section{WSTĘP}

Pandemia COVID-19, wywołana koronawirusem SARS-CoV-2, dotarła do większości krajów i społeczeństw na świecie. Dla większości osób młodych nowa odmienna rzeczywistość, w jakiej się znaleźli, była czymś nieznanym i trudnym do zaakceptowania. Transformacji uległo wiele wymiarów życia, począwszy od więzi społecznych przez aspekty socjologiczne, prawne, polityczne, czy w końcu te związane z cyfryzacją (Gorynia, 2020). Znamienny jest również fakt, że młodych Polaków określić można jako reprezentantów społeczeństwa ponowoczesnego, o czym świadczą ich cechy zbieżne z tą koncepcja tj.: konsumpcjonizm, indywidualizm, negacja uniwersalnych pojęć oraz obiektywnej prawdy (Miczyńska-Kowalska, 2013), czy też negatywne ustosunkowanie się do wszelkich ograniczeń. Do trendów, jakie identyfikują społeczeństwo ponowoczesne, należą: dynamiczny przepływ informacji (gospodarka oparta na wiedzy, gdzie produkcja towarów i usług w dużej mierze zależy od 
przekazywania informacji) (Szacka, 2003), bądź też mobilność przejawiająca się nieograniczonym, intensywnym ruchem ludzi (Mamzer, 2020). Wspomniana jako druga mobilność w dobie pandemii została szczególnie ograniczona dla przeciwdziałania negatywnym skutkom przenoszenia się wirusa. $Z$ tego też powodu celem niniejszych badań była analiza wpływu wprowadzonych obostrzeń na funkcjonowanie młodych ludzi w Polsce. Mimo faktu, iż to osoby młode (24-34 rok życia) oceniane były jako grupa wiekowa, która w największym stopniu lekceważyła zagrożenia związane z epidemią (CBOS, 2020) to jednocześnie grupa ta znacznie odczuła negatywne konsekwencję obostrzeń i lockdownu.

W opisywanym badaniu grupa wiekowa w przedziale 18-28 lat wybrana została z uwagi na chęć zweryfikowania tego, jak obostrzenia postrzegane są przez studentów, a więc w znakomitej większości osoby będące w wybranym przedziale wiekowym. Warto zaznaczyć, iż w prawdzie wiek określony w badaniu CBOS nie jest w pełni zbieżny z wiekiem respondentów w analizowanym badaniu, co jednakże nie stanowi przeszkody do tego, by ogólne tendencje i konkluzje z badania CBOS miały zastosowanie w tej analizie. Należy jednak określić, że ze względu na ograniczoną liczebność respondentów (309 osób) i dobór próby badawczej, niniejsza analiza nie ma charakteru reprezentatywnego dla całej młodzieży w Polsce.

Jako następstwa zamknięcia gospodarki wskazać można ograniczenie działalności placówek oświaty, instytucji kultury, branży eventowej, jak również zakaz zgromadzeń czy zawieszenie działalności basenów, siłowni itp. W rezultacie utożsamiane jest to z możliwością wystąpienia negatywnych konsekwencji dla zdrowia psychicznego ludzi młodych (zwłaszcza tych poniżej 18. roku życia) (Nearchou, Flinn, Niland, Subramaniam \& Hennessy, 2020), notabene nie przyzwyczajonych do ograniczeń swobód w takim zakresie. Obecnie duże znaczenie dla człowieka pełni autonomia i swoboda przemieszczania, a wartości takie, jak: równość, wolność i sprawiedliwość pełnią istotne znaczenie (Jennings \& Graham, 1996). Stąd też w poniższych badaniach przedstawiony zostanie postrzegany wpływ wdrożonych obostrzeń na funkcjonowanie osób młodych w Polsce. 
Postrzegany wpływ COVID-19 i związanych z nim ograniczeń

\section{METODY I NARZĘDZIA BADAWCZE}

Niniejszy artykuł oparty został na badaniu metodą sondażu diagnostycznego, z wykorzystaniem autorskiego kwestionariusza ankiety. Badanie skierowane było do osób młodych, których granice wiekowe wyznaczone zostały na 18-28 lat. Dane gromadzone były w pierwszym tygodniu grudnia 2020 roku za pomocą kwestionariusza ankietowego online, z zapewnieniem anonimowości respondentów. Próba badawcza wyniosła 309 osób, z czego 308 osób mieściło się w wyznaczonych granicach wiekowych. Celem głównym badania była próba znalezienia odpowiedzi na pytanie: jak osoby młode postrzegają słuszność wprowadzonych obostrzeń w związku z pandemią koronawirusa? Do osiągnięcia celu głównego wyznaczone zostały trzy cele szczegółowe, odnoszące się do następujących kwestii:

1. Tempo zmian w świetle opinii osób młodych.

2. Kompleksowość zmian a ich zrozumienie przez osoby młode.

3. Celowość zmian według osób młodych.

Do każdego z ww. celów postawione zostało przynajmniej jedno pytanie badawcze, odpowiednio:

1. Czy wprowadzane ograniczenia były zapowiadane z wystarczającym wyprzedzeniem?

2. Czy obowiązki nakładane przez państwo wyjaśniane były w sposób przejrzysty?

3. Czy zmiany, które zostały wprowadzone, były konieczne?

Płeć została uwzględniona jako zmienna dychotomiczna: Mężczyzna (0) lub Kobieta (1). Kobiety stanowiły zdecydowaną większość badanych, to jest $72,4 \%$. Na wykresie poniżej przedstwiony został podział respondentów według płci. Prezentowane badanie nie może być uznane za reprezentatywne dla całej młodzieży w Polsce.

Badanie było realizowane za pomocą autorskiego kwestionariusza ankiety przy wykorzystaniu narzędzia Formularze Google, który został udostępniony na grupach studenckich w mediach społecznościowych oraz innych grupach zrzeszających ludzi młodych w Polsce. 
Wykres 1. Struktura płci respondentów

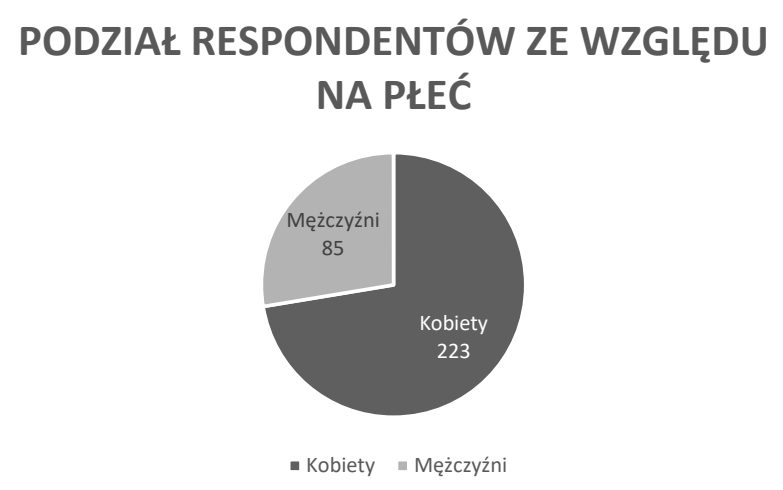

Źródło: opracowanie własne na podstawie przeprowadzonych badań.

W badaniu respondentom umożliwiono wybór jednej z dwóch zaproponowanych płci. Pominięte zostały warianty „inna” bądź jakakolwiek płeć kulturowo-społeczna. W badaniu kobiety stanowiły 2,62 razy liczniejszą grupę respondentów niż mężczyźni, których udział wynosił 27,6\% ogólnej liczby osób.

\section{ZAGADNIENIA PRAWNE DOTYCZĄCE OBOSTRZEŃ W POLSCE}

Pierwszy zarejestrowany przypadek COVID-19 na świecie został rozpoznany końcem grudnia 2019 roku, w Polsce zaś był to 4 marca 2020 roku. Na dwa dni przed tą datą uchwalona została przez Sejm „ustawa koronawirusowa” mająca na celu zapobieganie, przeciwdziałanie i zwalczanie COVID-19, innych chorób zakaźnych oraz wywołanych nimi sytuacji kryzysowych (Dz.U. 2020 poz. 374). Ustawa ta stała się prawną podstawą zwalczania epidemii (warto jednak zaznaczyć, że w Polskim porządku prawnym od roku 2008 istnieje ustawa o zapobieganiu oraz zwalczaniu zakażeń i chorób zakaźnych u ludzi, która stanowi istotne źródło prawa i podstawę do wydawanych rozporządzeń, na mocy których wprowadzano obostrzenia 
oceniane przez respondentów badania, a która z uwagi na pandemię doczekała się kilkunastu nowelizacji).

Sukcesywnie wraz z rozrostem pandemii uchwalane zaczęły być kolejne akty normatywne, jednakże wielość tych aktów tworzonych na potrzeby walki z pandemią jak również ich złożoność sprawiły, iż miał miejsce chaos informacyjny. $Z$ tego względu na potrzeby pracy wybrane i syntetycznie opisane zostały akty najbardziej relewantne. Uregulowania te zostały uporządkowane w tabeli $1 \mathrm{w}$ kolejności chronologicznej.

Tabela 1. Rozporządzenia wprowadzające obostrzenia

\begin{tabular}{|c|c|}
\hline Rozporządzenie & Wybrane zmiany \\
\hline $\begin{array}{l}\text { Rozporządzenie Ministra Edukacji } \\
\text { Narodowej z dnia } 11 \text { marca } \\
2020 \text { r. w sprawie czasowego } \\
\text { ograniczenia funkcjonowania } \\
\text { jednostek systemu oświaty } \\
\text { w związku z zapobieganiem, } \\
\text { przeciwdziałaniem i zwalczaniem } \\
\text { COVID-19 (Dz.U. } 2020 \text { poz. 410). }\end{array}$ & $\begin{array}{l}\text { Rozporządzenie to wprowadziło czasowe } \\
\text { ograniczenie funkcjonowania jednostek } \\
\text { systemu oświaty. Obowiązywało ono do } 31 \\
\text { sierpnia } 2020 \text { r., po czym zostało zastąpione } \\
\text { kolejnym analogicznym rozporządzeniem. }\end{array}$ \\
\hline $\begin{array}{l}\text { Rozporządzenie Ministra } \\
\text { Zdrowia z dnia } 20 \text { marca } 2020 \text { r. } \\
\text { w sprawie ogłoszenia na obszarze } \\
\text { Rzeczypospolitej Polskiej stanu } \\
\text { epidemii (Dz.U. } 2020 \text { poz. 491). }\end{array}$ & $\begin{array}{l}\text { Rozporządzeniem tym ówczesny minister } \\
\text { zdrowia Łukasz Szumowski wprowadził na } \\
\text { obszarze RP stan epidemii, obowiązujący do } \\
\text { odwołania (w chwili pisania tekstu jest to } \\
\text { prawie rok obowiązywania tego aktu). W akcie } \\
\text { określone zostały również szczegółowe } \\
\text { regulacje dotyczące przemieszczania się, } \\
\text { jak i obowiązkowej kwarantanny dla osób } \\
\text { przekraczających granice państwową. }\end{array}$ \\
\hline $\begin{array}{l}\text { Rozporządzenie Ministra } \\
\text { Zdrowia z dnia } 24 \text { marca } 2020 \text { r. } \\
\text { zmieniające rozporządzenie } \\
\text { w sprawie ogłoszenia na obszarze } \\
\text { Rzeczypospolitej Polskiej stanu } \\
\text { epidemii (Dz.U. } 2020 \text { poz. 522). }\end{array}$ & $\begin{array}{l}\text { Rozporządzenie to wzbudziło wiele emocji } \\
\text { z uwagi na wprowadzony nim zakaz } \\
\text { przemieszczania się (Turek, 2020). Polegał on } \\
\text { na zakazie przemieszczania się na obszarze } \\
\text { kraju w okresie od } 25 \text { marca do } 11 \text { kwietnia. } \\
\text { Wyjątkami było przemieszczanie się w celu } \\
\text { wykonywania czynności zawodowych, } \\
\text { zaspokajaniu niezbędnych potrzeb związanych } \\
\text { z bieżącymi sprawami życia codziennego } \\
\text { czy też uczestnictwa w sprawowaniu } \\
\text { kultu religijnego. Co więcej, podczas } \\
\text { przemieszczania się pieszo wymagane było } \\
\text { zachowanie odległości 1,5 między osobami, jak } \\
\text { również maksymalnie obok siebie poruszać się } \\
\text { mogły dwie osoby. W akcie tym ograniczono } \\
\text { również limit osób podczas sprawowania } \\
\text { kultu religijnego, jak i zakazano organizowania } \\
\text { zgromadzeń. }\end{array}$ \\
\hline
\end{tabular}




\begin{tabular}{|c|c|}
\hline $\begin{array}{l}\text { Rozporządzenie Rady Ministrów } \\
\text { z dnia } 31 \text { marca } 2020 \text { r. w sprawie } \\
\text { ustanowienia określonych } \\
\text { ograniczeń, nakazów i zakazów } \\
\text { w związku z wystąpieniem stanu } \\
\text { epidemii (Dz.U. } 2020 \text { poz. 566). }\end{array}$ & $\begin{array}{l}\text { Za sprawą przytoczonego rozporzádzenia } \\
\text { ograniczono funkcjonowanie określonych } \\
\text { instytucji (zwiazzanych z uprawianiem } \\
\text { i wykonywaniem sportu, fryzjerstwem czy } \\
\text { też wykonywaniem usług hotelarskich) lub } \\
\text { zakładów pracy. }\end{array}$ \\
\hline $\begin{array}{l}\text { Rozporządzenie Rady Ministrów } \\
\text { z dnia } 10 \text { kwietnia } 2020 \text { r. w sprawie } \\
\text { ustanowienia określonych } \\
\text { ograniczeń, nakazów i zakazów } \\
\text { w związku z wystapieniem stanu } \\
\text { epidemii (Dz.U. } 2020 \text { poz. 658). }\end{array}$ & $\begin{array}{l}\text { Rozporządzeniem tym nałożono powszechny } \\
\text { obowiązek zakrywania ust i nosa poza adresem } \\
\text { zamieszkania lub miejsca stałego pobytu } \\
\text { w terminie od } 16 \text { kwietnia do odwołania } \\
\text { (w rozporządzeniu tym zezwalano na } \\
\text { zakrywanie ust i nosa np. przy użyciu części } \\
\text { odzieży, przyłbic bądź też chust czy szalików. } \\
\text { Obostrzenie to zostało później zmienione } \\
\text { Rozporządzeniem Rady Ministrów z dnia } 26 \\
\text { lutego 2021, w którym zakazano zasłaniania ust } \\
\text { oraz nosa za pomocą wymienionych wcześniej } \\
\text { środków, zezwalając jedynie na zasłanianie } \\
\text { twarzy maseczkami). }\end{array}$ \\
\hline $\begin{array}{l}\text { Rozporządzenie Rady Ministrów } \\
\text { z dnia } 14 \text { października } 2020 \mathrm{r} . \\
\text { zmieniające rozporządzenie } \\
\text { w sprawie ustanowienia } \\
\text { określonych ograniczeń, } \\
\text { nakazów i zakazów w związku } \\
\text { z wystąpieniem stanu epidemii } \\
\text { (Dz.U. } 2020 \text { poz. 1797). }\end{array}$ & $\begin{array}{l}\text { Rada Ministrów w wymienionych } \\
\text { w rozporządzeniu obiektach w terminie od } \\
15 \text { października wprowadziła godziny dla } \\
\text { seniorów, uprawniające wyłącznie osoby } \\
\text { powyżej } 60 \text {. roku życia do bycia obsłużonym } \\
\text { w placówkach handlowych i usługowych } \\
\text { w dni powszednie między godziną } 10 \text { a } 12 . \\
\text { Obostrzenie to obowiązywało do } 1 \text { lutego. }\end{array}$ \\
\hline $\begin{array}{l}\text { Rozporządzenie Rady Ministrów } \\
\text { z dnia } 23 \text { października } 2020 \mathrm{r} . \\
\text { zmieniające rozporządzenie } \\
\text { w sprawie ustanowienia } \\
\text { określonych ograniczeń, } \\
\text { nakazów i zakazów w związku } \\
\text { z wystąpieniem stanu epidemii } \\
\text { (Dz.U. } 2020 \text { poz. } 1871 \text { ). }\end{array}$ & $\begin{array}{l}\text { Z dniem } 24 \text { października } 2020 \text { r. cała Polska } \\
\text { objęta została czerwoną strefa, co oznaczało, } \\
\text { iż jednakowe obostrzenia stosowane były na } \\
\text { terenie całego kraju. Wcześniej obostrzenia } \\
\text { przybierały różne formy w zależności od liczby } \\
\text { zakażeń w danym powiecie. Rozporządzeniem } \\
\text { tym nałożono na młodzież do 16. roku życia } \\
\text { obowiązek przemieszczania się wyłącznie pod } \\
\text { opieką osoby dorosłej. }\end{array}$ \\
\hline $\begin{array}{l}\text { Rozporządzenie Rady Ministrów } \\
\text { z dnia } 30 \text { października } 2020 \mathrm{r} . \\
\text { zmieniające rozporządzenie } \\
\text { w sprawie ustanowienia } \\
\text { określonych ograniczeń, } \\
\text { nakazów i zakazów w związku } \\
\text { z wystąpieniem stanu epidemii } \\
\text { (Dz.U. } 2020 \text { poz. 1917) }\end{array}$ & $\begin{array}{l}\text { W okresie od } 31 \text { października do } 2 \text { listopada } \\
2020 \text { r. nałożono obostrzenie polegające na } \\
\text { zakazie wstępu na teren cmentarzy. }\end{array}$ \\
\hline
\end{tabular}

Źródło: opracowanie własne.

Jak zostało wcześniej wspomniane, mnogość tworzonych aktów nie stanowiła jedynego problemu (w okresie roku od marca 2020 do marca 2021 roku samych tylko rozporządzeń Rady Ministrów wydanych zostało 50 (SUWwK, 2021). Do aktów prawnych w sprawie 
koronawirusa doliczyć można rozporządzenia Ministra Zdrowia, rozporządzenia Ministra Edukacji Narodowej, polecenia, decyzje, obwieszczenia i zarządzenia właściwych organów administracji czy też rzecz jasna ustawy). Wydawane akty od samego początku pandemii spotykały się z wątpliwościami części środowiska prawniczego, co do ich konstytucyjności oraz legalności. Obowiązkiem władz publicznych - wynikającym z konstytucji - jest przeciwdziałanie pandemii, jednakże zwykłe środki pozostające do dyspozycji decydentów są niewystarczające do tego, by zwalczać zagrożenie (Tuleja, 2020), stąd zastosowanie winny mieć przewidziane w konstytucji stany nadzwyczajne. Modelowo wszelkie ograniczanie wolności i praw obywateli powinno wynikać z ustawy, stąd - jak podkreślał Rzecznik Praw Obywatelskich Adam Bodnar - wydawane obostrzenia powinny spełniać kryterium proporcjonalności (tj. odpowiadać rzeczywistym potrzebom), a tryb, w jakim są one ogłaszane, powinien $\mathrm{w}$ demokratycznym państwie prawa spełniać standardy przewidzenie przez konstytucję (Krzewicki, 2020). Ponadto, co zostało wskazane, niejednokrotnie kolizja uregulowań z przepisami wynikała z braku klarowności i ostrości obostrzeń, jak również ze zróżnicowanych interpretacji ich wykładni (Baran, Burek \& Gibek 2020). Analizując dotychczasową linię orzeczniczą polskich sądów, można wskazać, że w zdecydowanej większości przypadków stały one po stronie przedsiębiorców. W przypadku menadżerki klubu w Sopocie, który otworzono wbrew zakazowi, wyrażonemu w rozporządzeniu, sąd odmówił wszczęcie postępowania uzasadniając, że ograniczenie wolności gospodarczej jest dopuszczalne jedynie w drodze ustawy i tylko ze względu na ważny interes publiczny (sygn. II W 746/20). Wskazano więc tutaj, że prawo zakazujące określonych działalności zostało wprowadzone w nieodpowiedni sposób. Wyniki uniewinniające zapadały także w sądach administracyjnych, gdzie uchylano nałożone przez Sanepid kary administracyjne na przedsiębiorców (II SA/Bd 642/20, II SA/Sz 765/20, II SA/Op 219/20).

Pomimo kilku korzystnych dla przedsiębiorców wyroków nie jest pewne, czy w każdej sytuacji zapadły wyrok będzie równie pozytywny. Polskie prawo nie jest bowiem oparte na precedensach, co oznacza, że każdy sędzia może dokonywać własnych interpretacji prawa, stąd też wyroki zapadające $\mathrm{w}$ sprawie legalności obostrzeń mogą zapadać zarówno na korzyść obywateli, jak i Państwowej Inspekcji 
Sanitarnej. W tym sporze rozstrzygające może być stanowisko Naczelnego Sądu Admiracyjnego, które może wyznaczyć tzw. linię orzeczniczą zgodnie z którą Sądy Administracyjne będą wydawać wyroki w analogicznych sprawach.

\section{WYNIKI ANALIZY NAUKOWEJ}

W pierwszym pytaniu spośród trzynastu przedstawionych obostrzeń poproszono respondentów, by ocenili w skali od 1 do 5 , które z podanych obostrzeń ich zdaniem najbardziej wpłynęły na swobody obywatelskie; ocena 1 oznaczała najmniejszy wpływ, a 5 największy. Wśród obostrzeń, jakie mogli ocenić respondenci, znalazły się:

- Obowiązek zakrywania ust i nosa w przestrzeni publicznej;

- Zakaz zgromadzeń powyżej pięciu osób;

- Zamknięcie cmentarzy podczas uroczystości Wszystkich Świętych;

- Zawieszenie działalności placówek kultury (kina, teatry, muzea);

- Zawieszenie działalności basenów, siłowni itp.;

- Ograniczenie liczby osób w środkach transportu publicznego, sklepach, kościołach;

- Godziny dla seniorów;

- Obowiązek nauczania zdalnego;

- Obowiązek przemieszczania się dzieci do 16. roku życia pod opieką rodzica lub opiekuna;

- Zamknięcie sklepów w galeriach handlowych;

- Ograniczenie działalności lokali gastronomicznych (organizowanie jedzenie wyłącznie na wynos);

- Ograniczenie liczby gości na weselach;

- Przymusowa kwarantanna (dla osób przyjeżdżających z zagranicy; osób, które miały kontakt z osobami zakażonymi lub potencjalnie zakażonymi koronawirusem).

Tym obostrzeniem, które najbardziej wpłynęło na swobody obywatelskie wśród całości respondentów, było ograniczenie działalności lokali gastronomicznych (organizowanie jedzenia wyłącznie na wynos) ze średnią wynoszącą 4,15. Za najmniej ograniczający te swobody uznany został zaś obowiązek zakrywania ust i nosa w przestrzeni publicznej ze średnią 2,87. 
Postrzegany wpływ COVID-19 i związanych z nim ograniczeń

Tabela 2. Obostrzenia, które w największym oraz najmniejszym stopniu wpłynęły na swobody obywatelskie z podziałem na płeć

\begin{tabular}{|l|l|l|}
\hline & Wśród mężczyzn & Wśród kobiet \\
\hline $\begin{array}{l}\text { W najmniejszym } \\
\text { stopniu }\end{array}$ & $\begin{array}{l}\text { Obowiązek zakrywania } \\
\text { ust i nosa w przestrzeni } \\
\text { publicznej }\end{array}$ & $\begin{array}{l}\text { Obowiązek zakrywania } \\
\text { ust i nosa w przestrzeni } \\
\text { publicznej }\end{array}$ \\
\hline $\begin{array}{l}\text { W największym } \\
\text { stopniu }\end{array}$ & $\begin{array}{l}\text { Ograniczenie działalności } \\
\text { lokali gastronomicznych } \\
\text { (organizowanie jedzenie } \\
\text { wyłącznie na wynos) }\end{array}$ & $\begin{array}{l}\text { Zakaz zgromadzeń powyżej } \\
\text { pięciu osób }\end{array}$ \\
\hline
\end{tabular}

Źródło: opracowanie własne na podstawie przeprowadzonych badań.

Obowiązek zakrywania ust i nosa w przestrzeni publicznej to obostrzenie, które w opinii badanych respondentów w najmniejszym stopniu wpłynęło na swobody obywatelskie. Ograniczenie to dotyczyło pierwotnie konieczności zasłaniania ust i nosa w przestrzeni zamkniętej (np. sklepy), stopniowo w miarę rozszerzania się epidemii zdecydowano się przenieść ten wymóg także na przestrzeń otwartą (np. ulica). W początkowym etapie rozprzestrzeniania się pandemii Ministerstwo Zdrowia dopuściło stosowanie maseczek, przyłbic lub części odzieży, takich jak komin, szalik. Obecnie zgodnie z Rozporządzeniem Rady Ministrów z dnia 26 lutego 2021 r. w sprawie ustanowienia określonych ograniczeń, nakazów i zakazów w związku z wystąpieniem stanu epidemii konieczne staje się stosowanie maseczek, a przyłbice i części odzieży mogą być stosowane jedynie dodatkowo, a nie jako zamiennik maseczki (Dz.U. 2021 poz. 367). Na przeciwstawnym biegunie są obostrzenia wpływające na swobody obywatelskie w największym stopniu, wśród których znalazły się ograniczenie działalności gastronomii oraz zakaz zgromadzeń powyżej pięciu osób. W Polsce w związku z zarządzonym 12 marca 2020 stanem zagrożenia epidemicznego (a od 20 marca tr. stanem epidemii) praktycznie zabroniono działalności lokali gastronomicznych (Dz.U. 2020 poz. 433). Niektóre obiekty gastronomiczne działały w ograniczony sposób, oferując jedzenie na wynos. Stan ten utrzymywał się przez ponad dwa miesiące (14 marca-18 maja), gdy rząd zezwolił tej branży na powrót do działania w ścisłym reżimie sanitarnym, w którym na 1 klienta miało przypadać co najmniej 4 metry kwadratowe powierzchni (Dz.U. 2020 poz. 878). Ten stan z kolei obowiązywał do początku sierpnia 2020 roku, gdy wraz ze 
wzrostem zakażeń wprowadzono podział Polski na strefy zieloną, żółtą i czerwoną. W strefie żółtej i zielonej lokale gastronomiczne mogły działać bez ograniczeń, a w strefie czerwonej ich funkcjonowanie skrócono do godziny 22 (Pot.gov.pl, 2021). Obecnie w chwili pisania tego artykułu lokale gastronomiczne działają w ścisłym reżimie sanitarnym z możliwością udostępniania nie więcej niż $75 \%$ liczby miejsc w lokalu (Gov.pl, 2021.07.07). Jak zwraca uwagę M. Grochowicz, zakaz działalności uderzył mocno w branżę gastronomiczna, lecz niektóre rodzaje gastronomii, takie jak pizzerie i restauracje, które już przed pandemią oferowały dania na wynos, poradziły sobie $\mathrm{z}$ tą sytuacją relatywnie lepiej (Grochowicz, 2020).

W przypadku zakazu zgromadzeń początkowo dotyczył on zgromadzeń liczących więcej niż 50 osób (Dz.U. 2020 poz. 433). Następne obostrzenia $\mathrm{w}$ tym zakresie podjęto, gdy dokonano podziału kraju na strefy żółte, zielone i czerwone, w zależności od sytuacji epidemiologicznej $\mathrm{w}$ danym regionie. $Z$ każdą $\mathrm{z}$ tych stref wiązany się inne zasady i ograniczenia. W strefie zielonej obostrzenia miały łagodniejszy charakter, pozwolono na organizacje zgromadzeń i wesel do 100 osób, w strefie żółtej do 75 osób, a w czerwonej limit ten wynosił 50 osób. Aktualnie obowiązuje przepis, w świetle którego w zgromadzeniu może uczestniczyć do 150 osób, co w porównaniu z wcześniej obowiązującymi regulacjami zezwalającymi na zgromadzenia do maksymalnie pięciu osób stanowi istotne poluzowanie restrykcji. Co istotne, w niniejszym badaniu obostrzenie dotyczące zakazu zgromadzeń zostało uznane za najbardziej uciążliwe przez ankietowane kobiety. Sytuacja ta może mieć związek z odbywającymi się w Polsce ogólnopolskimi protestami przeciwko zaostrzeniu przepisów dotyczących aborcji w Polsce. Należy w tym przypadku zauważyć, że respondentami były zazwyczaj osoby młode, z dużych miast, gdzie skala poparcia dla tego typu inicjatyw jest wyższa niż ma to miejsce $\mathrm{w}$ reszcie kraju.

\subsection{Tempo i częstotliwość wprowadzania ograniczeń}

Kolejną analizowaną kwestią było tempo i częstotliwość, z jaką wprowadzano ograniczenia związane $z$ rozprzestrzenianiem się COVID-19. Sytuacja związana $\mathrm{w}$ rozprzestrzenianiem się epidemii 
w Polsce ma charakter dynamiczny, jednak ważne jest, aby z możliwie jak największym wyprzedzeniem informować przedsiębiorców i całe społeczeństwo o wprowadzanych zmianach. Niestety, jak wskazuje praktyka, nowe rozporządzenia dotyczące obostrzeń są publikowane w Dzienniku Ustaw tuż przed ich wejściem w życie, na co zwracał uwagę między innymi Rzecznik Praw Obywatelskich (Rpo.gov.pl, 2020). W niniejszym badaniu respondenci mogli ocenić, czy obostrzenia były wprowadzane z odpowiednim wyprzedzeniem, zaznaczając na skali od 1 do 5 , gdzie 1 oznaczało zbyt szybkie tempo wprowadzania zmian, by się z nimi zapoznać, a 5 zupełnie wystarczający czas na zapoznanie się z ogłaszanymi obostrzeniami.

Wykres 2. Tempo wprowadzania zmian w obostrzeniach

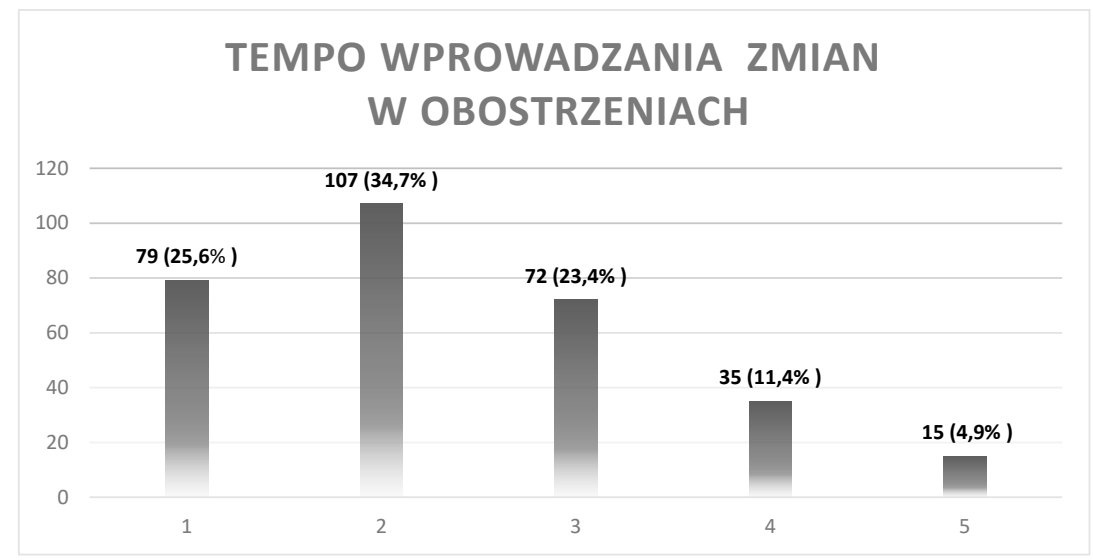

Źródło: opracowanie własne na podstawie przeprowadzonych badań.

Ogólna tendencja w aspekcie tempa wprowadzanych zmian wykazała, iż według ankietowanych nie były one wprowadzane z wystarczającym wyprzedzeniem. Średnia ocen wśród 308 respondentów wyniosła 2,35. $Z$ tego też powodu można wysnuć wniosek, iż rząd przygotowując zmiany w prawie, w związku z obowiązującym stanem pandemii, powinien także zwrócić uwagę na tempo informowania społeczeństwa o nich. 
Tabela 3. Rozkład średniej w skali 1-5 z podziałem na płeć

\begin{tabular}{|l|c|c|}
\hline & Mężczyźni & Kobiety \\
\hline Średnia & 2,42 & 2,32 \\
\hline
\end{tabular}

Źródło: opracowanie własne na podstawie przeprowadzonych badań.

Jak wynika danych z umieszczonych w tabeli nr 3 sposób informowania społeczeństwa o zmianach w prawie był negatywnie oceniany zarówno przez kobiety, jak i mężczyzn i nie odnotowano w tym przypadku znaczących różnic.

\subsection{Kompleksowość}

Kolejne pytanie brzmiało następująco: czy obostrzenia nakładane przez państwo wyjaśniane i obwieszczane były w sposób przejrzysty? Średnia ocena na skali od 1 do 5 wyniosła 2,66.

Wykres 3. Ocena przejrzystości obwieszczanych obostrzeń

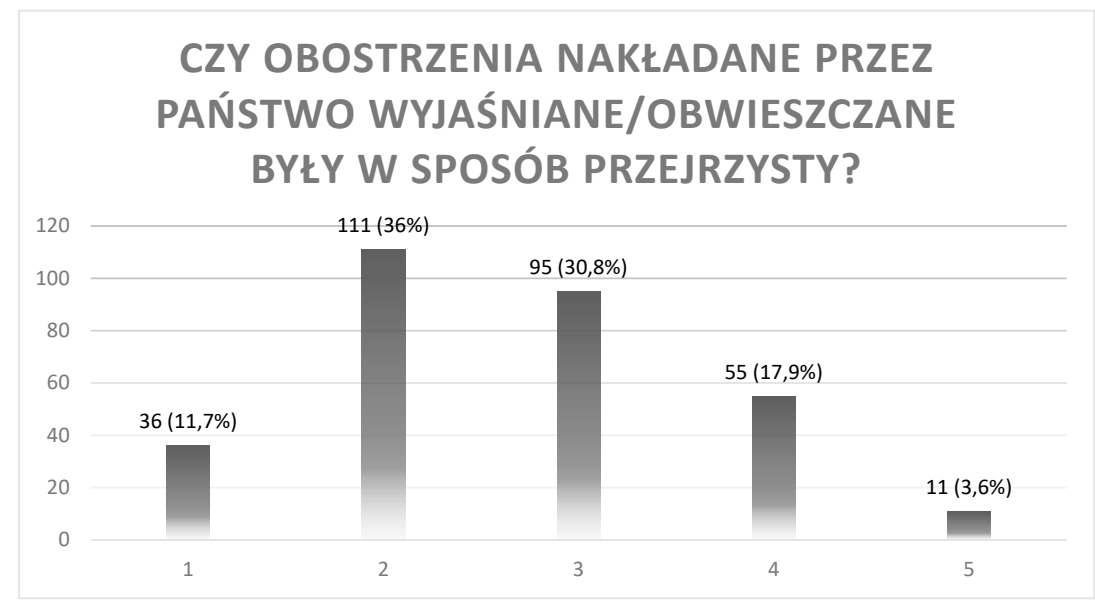

Źródło: opracowanie własne na podstawie przeprowadzonych badań. 
Postrzegany wpływ COVID-19 i związanych z nim ograniczeń

Tabela 4. Rozkład średniej w skali $1-5$ z podziałem na płeć

\begin{tabular}{|l|c|c|}
\hline & Mężczyźni & Kobiety \\
\hline Średnia & 2,46 & 2,73 \\
\hline
\end{tabular}

Źródło: opracowanie własne na podstawie przeprowadzonych badań.

Polska legislacja od wielu lat boryka się z niskim poziomem stanowionych aktów prawnych (Czucharski, Kozłowski, Wołejko \& Żukowska-Czaplicka, 2017). Również w przypadku ogłaszania obowiązujących obostrzeń sytuacja nie kształtuje się odmiennie. Wynika to explicite z oceny obostrzeń wśród osób młodych, gdzie przejrzystość wprowadzanych obostrzeń została negatywnie oceniona zarówno przez badane kobiety, jak i mężczyzn. Nadmierny pośpiech, stosowanie zbyt skomplikowanych i niezrozumiałych pojęć, czy też zbyt rozbudowane i niejasne sformułowania prowadzić moga do nadregulacji i niestabilności prawa, co spotyka się z protestem i sprzeciwem obywateli.

Jak więc wynika z przedstawionych danych, konieczne wydaje się, aby rządzący w sposób wyczerpujący i klarowny informowali społeczeństwo o powodach, dla których wprowadzają dane obostrzenia. W świetle przedstawionych danych można wysnuć wniosek, że politycy w niedostateczny sposób tłumaczą społeczeństwu, dlaczego wprowadzają dane obostrzenie, dlaczego dana działalność jest zamykana, a inna pozostaje otwarta itp. Stąd też kolejne decyzje dotyczące obostrzeń wymagają szerszego wyjaśnienia, tak aby była jasność, co do zasad ich przestrzegania.

\subsection{Celowość}

Przedmiotem niniejszych badań była także celowość wprowadzanych ograniczeń. Innymi słowy, badane były percepcje respondentów w zakresie zasadności wprowadzanych przez polski rząd ograniczeń. W kontekście słuszności wprowadzanych obostrzeń za najmniej celowe uznany został obowiązek przemieszczania się dzieci do 16. roku życia pod opieką rodzica lub opiekuna ze średnią 1,92. Jako najbardziej celowe przez respondentów wybrany został obowiązek zakrywania ust i nosa w przestrzeni publicznej, uzyskując średnią 3,68. 
Tabela 5. Ocena celowości wprowadzenia obostrzeń

\begin{tabular}{|l|l|l|}
\hline & \multicolumn{1}{|c|}{ Wśród mężczyzn } & \multicolumn{1}{c|}{ Wśród kobiet } \\
\hline $\begin{array}{l}\text { Najmniej } \\
\text { celowe }\end{array}$ & $\begin{array}{l}\text { Obowiązek przemieszczania } \\
\text { się dzieci do 16. roku życia pod } \\
\text { opieką rodzica lub opiekuna }\end{array}$ & $\begin{array}{l}\text { Obowiązek przemieszczania } \\
\text { się dzieci do 16. roku życia pod } \\
\text { opieką rodzica lub opiekuna }\end{array}$ \\
\hline $\begin{array}{l}\text { Najbardziej } \\
\text { celowe }\end{array}$ & $\begin{array}{l}\text { Obowiązek zakrywania ust i nosa } \\
\text { w przestrzeni publicznej }\end{array}$ & $\begin{array}{l}\text { Obowiązek zakrywania ust i nosa } \\
\text { w przestrzeni publicznej }\end{array}$ \\
\hline
\end{tabular}

Źródło: opracowanie własne na podstawie przeprowadzonych badań.

Jednomyślnie za najbardziej celowy wybrany został obowiązek zakrywania ust i nosa w przestrzeni publicznej (jest to niejako potwierdzenie wyników z pierwszego pytania, gdzie obostrzenie to zostało również uznane za najmniej ograniczające swobody osób młodych). Ze sporą krytyką spotkał się natomiast obowiązek przemieszczania się dzieci do 16. roku życia pod opieką rodzica lub opiekuna. Nie tylko w badanej grupie wiekowej obostrzenie było to negatywnie oceniane, ale szczególnie wśród nastolatków, których zakaz ten dotyczył bezpośrednio (Makaruk, Włodarczyk, Szredzińska, 2020). Zakaz ten uzasadniany był koniecznością ograniczenia mobilności młodzieży w okresie realizowana zdalnej edukacji i miał na celu ograniczenie transmisji wirusa COVID-19. Ograniczenie to spotkało się jednak z szeroką krytyką młodzieży, gdyż w dużym stopniu ograniczało ich możliwości w zakresie swobodnego wychodzenia z domu, w przypadku nieobecności rodziców

\section{WNIOSKI}

Przeprowadzone badania umożliwiły poznanie społecznych percepcji w zakresie wprowadzanych obostrzeń wśród ludzi młodych, z podziałem na płeć. Generalnie osoby młode krytycznie oceniały wprowadzone obostrzenia, co upatrywać można w przekonaniu, że ewentualne ryzyko związane z ciężkimi powikłaniami po COVID-19 jest w ich przypadku niższe niż u seniorów, a wszelkie próby ograniczania im swobód obywatelskich (nawet dla ich dobra) są - ich zdaniem - próbą naruszenia wolności (IAB, 2020).

Do końcowych wniosków niniejszych pracy można także zaliczyć następujące stwierdzenia: 
Postrzegany wpływ COVID-19 i związanych z nim ograniczeń

- Obostrzenia nie były wprowadzane z wystarczającym wyprzedzeniem czasowym.

- Informacje na temat obostrzeń nie były przekazywane w sposób zrozumiały.

- Wprowadzone obostrzenia według młodych osób nie były konieczne w takim wymiarze, w jakim zostały wprowadzone.

- Obowiązek zakrywania ust został oceniony najbardziej przychylnie wśród wszystkich obostrzeń.

Przeprowadzone badanie wpisuje się $\mathrm{w}$ bardzo aktualny i społecznie ważny temat obostrzeń związanych z pandemią. Jednak ze względu na ograniczony dobór próby, jak również zawężenie osób badanych do ludzi młodych w wieku 18-28 lat, nie można uznać je za holistycznie reprezentatywne, co stanowi pewne ograniczenie w prezentowaniu wniosków z niniejszych analiz. Stanowi ono jednak wstęp do dalszych badań, które można poszerzyć o dobór innych grup wiekowych, jak również dokonanie porównań pomiędzy innymi krajami, grupami zawodowymi czy kierunkami studiów, co otwiera dosyć duże pole do analiz i badań.

Funkcjonujące w Polsce obostrzenia stanowią znaczne obciążenie dla całego społeczeństwa, które pragnie wrócić do „normalności” i życia bez maseczek, z funkcjonującą gastronomia, klubami fitness, i innymi ważnymi dla ludzi usługami. W opinii polskiego rządu i wielu ekspertów szansą na pokonanie wirusa COVID-19 jest narodowy program szczepień, który jest obecnie w Polsce realizowany. Zgodnie z danymi aktualnymi na dzień 12 lipca 2021 r. w Polsce dotychczas wykonano ponad $31 \mathrm{mln}$ szczepień, a liczba zaszczepionych obiema dawkami wynosi blisko $15 \mathrm{mln}$ obywateli (Gov.pl, 2021).

\section{Bilbiografia}

Baran, K., Burek, W., Gibek. M. (2020). Wpływ Covid-19 na społeczeństwo i prawo. Wybrane aspekty polskich i europejskich regulacji prawnych. Rocznik administracji publicznej, 6, 282-289. DOI 10.4467/2 4497800RAP.20.016.12910.

CBOS (2020). Poczucie zagrożenia u progu epidemii koronawirusa. Komunikat z badań, 40, 3-8. https://www.cbos.pl/SPISKOM. POL/2020/K_058_20.PDF 
Czucharski, Ł., Kozłowski, Ł., Wołejko, P., Żukowska-Czaplicka, W. (2017). 7 grzechów głównych stanowienia prawa w Polsce. Raport legislacyjny za pierwsze 13 miesięcy Sejmu VIII kadencji 11.201512.2016. Pracodawcy Rzeczypospolitej Polskiej. https://pracodawcyrp. pl/upload/files/2017/07/raport-legislacyjny-pracodawcow-rp.pdf

Gorynia, M. (2020, 8 kwietnia). Koronawirus niejeden ma wymiar. https:// www.rp.pl/Opinie/200409383-Marian-Gorynia-Koronawirus-niejeden-ma-wymiar.html

Grochowicz, M. (2020). Sytuacja branży gastronomicznej w pierwszych miesiącach trwania pandemii COVID-19 na przykładzie Krakowa. Urban Development Issues, 67, 5-16.

IAB Polska (2020, 12 kwietnia). Zaufanie internautów a Covid-19. Raport z badania. https://www.iab.org.pl/baza-wiedzy/raport-zaufanie -internautow-a-covid-19/

Jennings, L.E., Graham, A.P. (1996). Postmodern Perspectives and Action Research: reflecting on the possibilities, Educational Action Research, 4(2), 267-278, DOI: 10.1080/0965079960040208.

Krzewicki, J. (2020). Relacje Kościół-Państwo w Polsce wobec pandemii COVID-19. Kościót i prawo, 9 (22), nr 1, 86-87.

Makaruk, K., Włodarczyk, J., Szredzińska, R. (2020), Negatywne doświadczenia młodzieży w trakcie pandemii, Raport z badań ilościowych, Fundacja Dajemy Dzieciom Siłę. https://fdds.pl/_Resources/ Persistent/5/0/0/e/500e0774b0109a6892ce777b0d8595f528adea62/Negatywne-doswiadczenia-mlodziezy-w-trakcie-pandemii.-Raport-z-badan-ilosciowych-1.pdf

Mamzer, H. (2020). Postmodern society and covid-19 pandemic: old, new and scary. Society register, 4(2), 14. DOI: 10.14746/sr.2020.4.2.01.

Miczyńska-Kowalska, M. (2013). Kultura konsumpcyjna cechą społeczeństwa ponowoczesnego. Zacieranie granic między kulturą niską a wysoką. Zeszyty Naukowe KUL, 56, 199-202.

Ministerstwo Rozwoju, Pracy i Technologii. (2021). Gastronomia. Gov. pl. https://www.gov.pl/web/rozwoj-praca-technologia/gastronomia Nearchou,F., Flinn, C., Niland,R., Subramaniam, S.S. \& Hennessy,E. (2020). Exploring the Impact of COVID-19 on Mental Health Outcomes in Children and Adolescents: A Systematic Review. International Journal of Environmental Research and Public Health, 17 (22), 849. DOI: 10.3390/ijerph17228479.

Polska Organizacja Turystyczna. (b.d.). Nowe zasady spotkań. Pot.gov.pl. https://www.pot.gov.pl/pl/pcb/news/nowe-zasady-spotkan

Rzecznik Praw Obywatelskich. (2020, 26 października). Adam Bodnar do premiera: najnowsze nakazy i zakazy nadal sprzeczne z Konstytucją. Rpo.gov.pl. https://www.rpo.gov.pl/pl/content/ 
Postrzegany wpływ COVID-19 i związanych z nim ograniczeń

rpo-do-premiera-najnowsze-nakazy-zakazy-nadal- sprzeczne-z-konstytucja

Serwis Rzeczypospolitej Polskiej. (2021). Raport szczepień przeciwko COVID-19. Gov.pl. https://www.gov.pl/web/szczepimysie/ raport-szczepien-przeciwko-covid-19

Śląski Urząd Wojewódzki w Katowicach. (2021). Akty prawne i dokumenty wydane w związku z COVID-19. Katowice.uw.gov.pl. https:// www.katowice.uw.gov.pl/aktualnosci/akty-prawne-i-dokumenty-dotyczace-zapobiegania-przeciwdzialania-i-zwalczania-covid-19

Szacka, B. (2003). Wprowadzenie do socjologii. Warszawa: Oficyna Naukowa. Tuleja, P. (2020). Pandemia Covid-19 a konstytucyjne stany nadzwyczajne. Palestra, 9.

Turek, R. (2020). Poszanowanie praw człowieka i obywatela w czasie pandemii COVID-19 na gruncie Konstytucji RP. W K. Stępniak (red.) Państwo i prawo w czasach COVID-19 (s. 78-0). Warszawa: Wydawnictwo Think \& Make.

\section{Akty prawne}

Rozporządzenie Ministra Edukacji Narodowej z dnia 11 marca 2020 r. w sprawie czasowego ograniczenia funkcjonowania jednostek systemu oświaty $\mathrm{w}$ związku z zapobieganiem, przeciwdziałaniem i zwalczaniem COVID-19 Dz.U. 2020 poz. 410 (2020) (Polska). https://isap.sejm.gov.pl/isap.nsf/download.xsp/WDU20200000410/O/ D20200410.pdf

Rozporządzenie Ministra Zdrowia z dnia 20 marca 2020 r. w sprawie ogłoszenia na obszarze Rzeczypospolitej Polskiej stanu epidemii Dz.U. 2020 poz. 491 (2020) (Polska). https://isap.sejm.gov.pl/isap. nsf/download.xsp/WDU20200000491/O/D20200491.pdf

Rozporządzenie Ministra Zdrowia z dnia 24 marca 2020 r. zmieniające rozporządzenie w sprawie ogłoszenia na obszarze Rzeczypospolitej Polskiej stanu epidemii Dz.U. 2020 poz. 522 (2020) (Polska). https://isap.sejm.gov.pl/isap.nsf/download.xsp/WDU20200000522/O/ D20200522.pdf

Rozporządzenie Rady Ministrów z dnia 31 marca 2020 r. w sprawie ustanowienia określonych ograniczeń, nakazów i zakazów w związku z wystapieniem stanu epidemii Dz.U. 2020 poz. 566 (2020) (Polska). https://isap.sejm.gov.pl/isap.nsf/download.xsp/WDU20200000566/O/ D20200566.pdf

Rozporządzenie Rady Ministrów z dnia 10 kwietnia 2020 r. w sprawie ustanowienia określonych ograniczeń, nakazów i zakazów w związku z wystąpieniem stanu epidemii Dz.U. 2020 poz. 658 (2020) (Polska). 
https://isap.sejm.gov.pl/isap.nsf/download.xsp/WDU20200000658/O/ D20200658.pdf

Rozporządzenie Rady Ministrów z dnia 14 października 2020 r. zmieniające rozporządzenie $\mathrm{w}$ sprawie ustanowienia określonych ograniczeń, nakazów i zakazów w związku z wystąpieniem stanu epidemii Dz.U. 2020 poz. 1797 (2020) (Polska). https://isap.sejm.gov.pl/isap.nsf/ download.xsp/WDU20200001797/O/D20201797.pdf

Rozporządzenie Rady Ministrów z dnia 23 października 2020 r. zmieniające rozporządzenie w sprawie ustanowienia określonych ograniczeń, nakazów i zakazów w związku z wystąpieniem stanu epidemii Dz.U. 2020 poz. 1871 (2020) (Polska). https://isap.sejm.gov.pl/isap.nsf/ download.xsp/WDU20200001871/O/D20201871.pdf

Rozporządzenie Rady Ministrów z dnia 30 października 2020 r. zmieniające rozporządzenie $w$ sprawie ustanowienia określonych ograniczeń, nakazów i zakazów w związku z wystąpieniem stanu epidemii Dz.U. 2020 poz. 1917 (2020) (Polska). https://isap.sejm.gov.pl/isap.nsf/ download.xsp/WDU20200001917/O/D20201917.pdf

Rozporządzenie Rady Ministrów z dnia 26 lutego 2021 r. w sprawie ustanowienia określonych ograniczeń, nakazów i zakazów w związku z wystapieniem stanu epidemii Dz.U. 2021 poz. 367 (2021) (Polska). https://isap.sejm.gov.pl/isap.nsf/download.xsp/WDU20210000367/O/ D20210367.pdf

Rozporządzenie Ministra Zdrowia z dnia 13 marca 2020 r. w sprawie ogłoszenia na obszarze Rzeczypospolitej Polskiej stanu zagrożenia epidemicznego Dz.U. 2020 poz. 433 (2020) (Polska). https://isap.sejm. gov.pl/isap.nsf/download.xsp/WDU20200000433/O/D20200433.pdf

Rozporządzenie Rady Ministrów z dnia 16 maja 2020 r. w sprawie ustanowienia określonych ograniczeń, nakazów i zakazów w związku z wystapieniem stanu epidemii Dz.U. 2020 poz. 878 (2020) (Polska). http://isap.sejm.gov.pl/isap.nsf/download.xsp/WDU20200000878/O/ D20200878.pdf

Rozporządzenie Rady Ministrów z dnia 10 marca 2021 r. zmieniające rozporządzenie $\mathrm{w}$ sprawie ustanowienia określonych ograniczeń, nakazów i zakazów w związku z wystąpieniem stanu epidemii Dz.U. 2021 poz. 436 (2021) (Polska). https://isap.sejm.gov.pl/isap.nsf/download.xsp/WDU20210000436/O/D20210436.pdf

Postanowienie Sądu Rejonowego w Sopocie z dnia 8 stycznia $2021 \mathrm{r}$. (sygn. II W 746/20). Pobrano z: https://www.rp.pl/Bezpieczenstwo/ 302239941-Sad-bez-kary-za-dyskoteke-podczas-epidemii-COVID-19. html (dostęp: 04.06.2021).

Ustawa z dnia 2 marca 2020 r. o szczególnych rozwiązaniach związanych z zapobieganiem, przeciwdziałaniem i zwalczaniem COVID-19, 
Postrzegany wpływ COVID-19 i związanych z nim ograniczeń

innych chorób zakaźnych oraz wywołanych nimi sytuacji kryzysowych Dz.U. 2020 poz. 374 (2020) (Polska). https://isap.sejm.gov.pl/ isap.nsf/download.xsp/WDU20200000374/T/D20200374L.pdf

Wyrok Wojewódzkiego Sądu Administracyjnego w Bydgoszczy z dnia 27 października 2020 r. II SA/Bd 642/20. Pobrano z: https://sip.lex.pl/ orzeczenia-i-pisma-urzedowe/orzeczenia-sadow/ii-sa-bd-642-20-wyrok-wojewodzkiego-sadu-523187770 (dostęp: 07.06.2021).

Wyrok Wojewódzkiego Sądu Administracyjnego w Szczecinie z dnia 11 grudnia 2020 r. II SA/Sz 765/20. Pobrano z: https://sip.lex.pl/orzeczenia-i-pisma-urzedowe/orzeczenia-sadow/ii-sa-sz-765-20-wyrok-wojewodzkiego-sadu-523202765 (dostęp: 04.06.2021).

Wyrok Wojewódzkiego Sądu Administracyjnego w Opolu z dnia 27 października 2020 r. II SA/Op 219/20. Pobrano z: https://sip.lex.pl/orzeczenia-i-pisma-urzedowe/orzeczenia-sadow/ii-sa-op-219-20-upowaznienie-ustawowe-niespelniajace-523187612 (dostęp: 09.06.2021).

Wyrok Wojewódzkiego Sądu Administracyjnego w Bydgoszczy z dnia 17 listopada 2020 r. II SA/Bd 834/20. Pobrano z: https://sip.lex.pl/orzeczenia-i-pisma-urzedowe/orzeczenia-sadow/ii-sa-bd-834-20-dzialalnosci-podlegajace-czasowemu-523207806 (dostęp: 10.06.2021).

\section{Copyright and License}

This article is published under the terms of the Creative Commons Attribution - NoDerivs (CC BY- ND 4.0) License http://creativecommons.org/licenses/by-nd/4.0/ 